\title{
Comparative Effects of Multisensory and Metacognitive Instructional Approaches on English Vocabulary Achievement of Underachieving Nigerian Secondary School Students
}

\author{
Folakemi.O. Adeniyi \\ Department of English, School of Languages \\ Kwara State College of Education, Ilorin, Nigeria \\ E-mail: Oyeyemi2009@gmail.com \\ R. Adebayo Lawal \\ Department of Arts and Social Sciences Education \\ University of Ilorin, Nigeria \\ E-mail: bayolawal58@yahoo.com
}

Received: February 21, 2011

Accepted: February 23, 2011 Published: February 1, 2012

doi:10.5539/ies.v5n1p18

URL: http://dx.doi.org/10.5539/ies.v5n1p18

\begin{abstract}
The purpose of this study was to find out the relative effects of three instructional Approaches i.e. Multisensory, Metacognitive, and a combination of Multisensory and Metacognitive Instructional Approaches on the Vocabulary achievement of underachieving Secondary School Students. The study adopted the quasi-experimental design in which a pre-test, post-test, non - randomized, non-equivalent control group design was employed. One hundred and twenty [120 students-60 males and 60 females] were selected from four secondary schools within the Ilorin metropolis through stratified random sampling technique. The four schools were categorized into three experimental groups and one control group according to the design of the study. The instructional programmes for the teachers and the achievement test for the students were prepared by the researcher from the students' English text books according to the curriculum specifications and the past questions from the JSS NECO past questions. Six major hypotheses were generated for the study. All of them were based on the general effects of the three instructional approaches on the underachieving students' vocabulary achievement. The results were analyzed using Analysis of Covariance [ANCOVA]. The Duncan Multiple Range Test was used to confirm which pairs of the variables were significantly different. The results revealed that there was a significant difference in the overall achievement of the students taught using the three approaches. In other words, each of the experimental group performed significantly better than the control group. However, the findings indicated that the Multisensory Instructional Approach [MSIA] was the most potent of the three modes. It was recommended that English Language teachers should consider the interest of the underachievers by employing the Multisensory approach to teach them.
\end{abstract}

Keywords: Multisensory, Metacognitive, Instructional approaches

\section{Introduction}

English language is the most widely used language by the non-native speakers, even though it is not the most widely spoken language. This makes the teaching of English as a second language a very important endeavor [Kittao 2003].The teaching of English to non native speakers is referred to as English as a foreign language [EFL] or English as a second language [ESL],depending on the historical context. Quirk and Smirth [1978] assert that English as a foreign language is now generally taken to mean teaching the language as a subject for purposes similar to those for which French and German were taught in USA. English as a second language means teaching English in situations where it serves as a language of wider communication and the medium of instruction in at least part of the educational system. Tiffen [1982] observes that the child growing up in English -speaking Africa, such as Nigeria, is surrounded by a complex language situation, for besides having to master his own and often a second or even third indigenous language, he also requires a thorough command of the English language, if he is to be educated in the modern sense of it. 
The core of a language involves the sound system, the syntactic structure and the vocabulary [Unoh 1987].But of prime importance among these is the vocabulary [Kruse 1979] The reader must know the meaning of enough of words in a sentence for it to make sense. He must also know how to combine individual word meanings within a sentence. Kim Seoh [1996] asserts that lexical competence implies more than just knowing what a word means. It subsumes a number of other kinds of knowledge including knowing what differentiates one word from the other words that appear to mean the same. Others include what other meanings a word might have. What links it has with other items in the lexicon, how it behaves syntactically and just as importantly, its limitation of use according to situation and function. This means that vocabulary instruction should go beyond just helping the learner to internalize dictionary meaning. A central purpose in teaching should be to encourage and help the learner to become more aware of how native speakers and other proficient speakers use the target language, and to be more sensitive to differences in nuances and shades of meaning.

This important teaching purpose is possible with average students who have no record of serious second language learning difficulty. For the under achievers on the other hand, English language teachers would need an explicit and distinctive approach to teach them. Gefen [1980] classified learners in a typical English language class into two types. They are able [achievers] and less able [underachievers]. The able students according to him learn according to the agreed syllabus and progress satisfactorily in all four skills. The less able students [underachievers] are still capable of learning, but they have difficulties and, all too often fail, they give up easily and soon become disillusioned. Much teaching efforts needed to be directed towards this set of students

Several reasons have been identified as the causes of underachievement in language learning. Thorne [2008] identifies slow maturation, fearfulness and anxiety, illness and bodily defects, aptitude and so on. Nelson [2006] identifies poor teaching strategy and poor instructional materials as the most important factors causing underachievement in ESL class. Yusuf [2001] defines instructional materials as different forms of information carriers, which are used to record, store, preserve, transmit, or retrieve information for the purpose of teaching and learning. They include textbooks, video, audio tapes, computer software and visual aids. From all the foregoing discussions, the importance of vocabulary in learning a new language is not in doubt. The causes of underachievement in English language have also been underscored, especially as they relate to the significant role which instructional materials and method play in ESL class, and the need to assist and motivate underachieving learners to experience achievement and progress.

\section{Statement of the Problem}

For a number of years, second language teachers have faced the perplexing issue of how to assist students who struggle to learn a second language [Ganshow, 1998]. Poor teaching strategies and poor instructional materials are identified as the most important factors of underachievement in learning English language [Nelson 1976]. This is because most teachers do not know the appropriate teaching strategies and methodology to adopt in teaching specific aspects of English language. In addition there has been increasing awareness about the special needs of individual with learning difficulties from areas in which cultural expectation includes the use of two or more languages as is the situation in Nigeria. As a result of this, there is a need for appropriate instructional approach that will help both the teachers and the students. Moreover most teachers have failed to see the importance of using teaching aids, which can be used for presentation, practice, revision, and testing in the ESL classroom. Students' interest is killed because they are bored with the traditional 'talk and board' teaching approach. Therefore there is a need to re-emphasize the use of learner-centered approaches that involve different teaching materials and several linguistic levels of vocabulary. An investigation into the comparative effects of such instructional approaches as the Multisensory and Metacognitive approaches on the vocabulary achievement of underachieving secondary school students thus becomes highly desirable, so as to ascertain the approaches that can best assist and motivate underachievers to experience achievement and progress.

\section{Purpose of the Study}

This study aims at finding

The comparative effects of Multisensory, Metacognitive and the combination of Multisensory and Metacognitive Instructional Approaches on English vocabulary learning of underachieving secondary school students in Ilorin Nigeria. Specifically, this study intends to investigate;

i. The effects of Multisensory Instructional Approach [MSIA] on underachieving secondary school students' achievement in pronunciation spelling, morphology, lexico-syntax and lexico-semantics]

ii. The effects of Metacognitive Instructional Approach (MCIA) on underachieving secondary school students' achievement in pronunciation spelling, morphology, lexico-syntax and lexico-semantics] 
iii. The effects of the combination of Multisensory, and Metacognitive Instructional Approaches on underachieving secondary school students' achievement in pronunciation, spelling, morphology, lexico-syntax and lexico-semantics]

\section{Research Questions}

i. Will there be any difference in the effects of multisensory, metacognitive, the combination of MSIA and MCIA, and the Conventional Instructional Approaches on vocabulary achievement of the underachievers?

ii. Will there be any difference in the effects of MSIA, MCIA, MSIA+MCIA and CIA on the pronunciation achievement of the underachieving students.

iii. Will there be any difference in the effects of MSIA, MCIA, MSIA+MCIA and CIA on the spelling achievement of the underachieving students.

iv. Will there be any difference in the effects of MSIA, MCIA, MSIA+MCIA and CIA on the morphological achievement of the underachieving students.

v. Will there be any difference in the effects of MSIA, MCIA, MSIA+MCIA and CIA on the lexico-syntax achievement of the underachieving students.

vi. Will there be any significant difference in the effects of MSIA, MCIA, MSIA+MCIA and CIA on the lexico-semantics achievement of the underachieving students.

\section{Research Hypotheses}

Ho$_{1}$ : There will be no significant difference in the effects of MSIA, MCIA, the combination of MSIA and MCIA Instructional Approaches and the Conventional Instructional Approach on the vocabulary achievement of the underachieving students

$\mathrm{Ho}_{2}$ : There will be no significant difference in the effects of MSIA, MCIA, MSIA+MCIA and CIA on the pronunciation achievement of the underachieving students.

$\mathbf{H o}_{3}$ : There will be no significant difference in the effects of MSIA, MCIA, MSIA+MCIA and CIA on the spelling achievement of the underachieving students.

$\mathrm{Ho}_{4}$ : There will be no significant difference in the effects of MSIA, MCIA, MSIA+MCIA and CIA on the morphology achievement of the underachieving students.

Ho: There will be no significant difference in the effects of MSIA, MCIA, MSIA+MCIA and CIA on the lexico-syntax achievement of the underachieving students.

Ho $_{6}$ : There will be no significant difference in the effects of MSIA, MCIA, MSIA+MCIA and CIA on the lexico-semantics achievement of the underachieving students

\section{Research Design}

This study adopted a quasi - experimental design of pretest- post-test, control group only. Therefore, a four by two by five factorial design was employed. Four levels of independent variables [treatment and control] and five levels of vocabulary dimensions were investigated in the study. This design permits the establishment of causal relationship between the independent and dependent variables. The interactive effects of the four instructional approaches on the vocabulary achievement of the underachievers were determined. The four instructional approaches are the independent variables and the five levels of vocabulary dimension are the dependent variables. Gains from these variables were measured in terms of the differences between the pre-test and post-test scores.

\section{Population, Sample and Sampling Technique}

All underachieving secondary school one students [SS1] in Ilorin metropolis are the target population for this study. However, based on quasi experimental design, which involves four groups, the stratified random sampling technique based on gender, school location, type of school, funding pattern, year of establishment, and teacher- student ratio were employed to select schools required for the study. There after four schools which are comparable in terms of the listed criteria were finally selected for the study and SS1 Arts students who consistently scored below $40 \%$ in English language were selected for the study.

\section{Instrumentation}

The following research instruments were designed by the researcher and used to gather data for the study

1a. The instructional programmes prepared for teachers is based on each instructional technique to suit each component of the experimental treatment as well as the control group. These manuals guided the teachers in their systematic teaching procedures. 
1b. The instructional manual prepared for the students which feature all the selected lexical items that could be found in the SSS English curriculum. All these lexical items have multisensory appeal.

2. The vocabulary achievement test [VAT] for the students. This contains the JSS3 Examination past questions that have multisensory appeal.

\section{Procedure for Data Collection}

This contains three stages. Stage one is the pretest and stage two is the administration of the test. All the 120 subjects selected for the study are divided into the three experimental and one control group, they all took part in the two tests. The test consisted of one hundred questions [twenty questions for each vocabulary dimension]. Each of the experimental teachers was attached to a particular group of underachievers. Stage three is the posttest. At the end of the teaching activity, the posttest was administered on all the four groups involved in the study. The same teachers who taught the students also administered the tests, while the researcher coordinated the exercise.

\section{Data Analysis Techniques}

After the treatment had been administered for a period of six weeks to the three experimental and control groups, a posttest was carried out on all the four groups. The ANCOVA [Analysis of covariance] statistic was used to determine whether there were any significant differences among the post-test scores with the pre-test score serving as covariates. This statistical method was preferred because it is robust enough to cater for this kind of study, which is quasi-experimental. Where significant difference existed, the Duncan Multiple Range test was used to confirm which pairs of the variables were significantly different.

\section{Presentation of Results}

Ho1: No significant difference in the effects of Multisensory Instructional Approach (MSIA), Metacognitive Instructional Approach (MCIA), the combination of MSIA and MCIA and the Conventional Instructional Approach on the vocabulary achievement of the underachieving students.

Insert Table 1 in here.

Table 1 shows that the calculated $\mathrm{f}$-value which is 48.11 was significant at $\mathrm{p}>0.05$, the hypothesis is rejected. This result indicates that the instructional approaches had significant effects on students' vocabulary achievement. From the table also, the treatment produced a significant difference from the post-test scores of the students when pre-test scores were used as covariates. Therefore, hypothesis one was rejected. A follow up of Duncan Multiple Range Test was conducted to determine the actual source of difference in the effectiveness of the variables investigated.

Insert Table 2 in here.

Table 2 shows the performance Mean scores for each group as well as the Duncan grouping in order to establish the source of difference. The result indicates that MSIA is the most effective, followed by MCIA and MSIA+MCIA. This means that the three approaches are more effective than the Conventional approach which is labeled ' $\mathrm{C}$ '. Therefore, significant difference exists between the three instructional approaches and the Conventional instructional approach.

Ho2: There will be no significant difference in the effects of MSIA, MCIA, MSIA+MCIA and CIA on the pronunciation achievement of the underachieving students.

Insert Table 3 in here.

Table 3 shows that the calculated $f$-value 26.84 was significant at $p>0.05$. The hypothesis is therefore rejected. This result indicates that all the instructional approaches had significant effect on students' pronunciation achievement. To identify which pairs of the variables are significantly different, a Duncan Multiple Range Test was carried out as illustrated in table 4.

Insert Table 4 in here.

Table 4 shows that MSIA which is rated ' $A$ ' is the most effective instructional approach for teaching English pronunciation to underachieving students.

Ho3: There will be no significant difference in the effectiveness of MSIA, MCIA, the combination of MSIA +MCIA and CIA on the Spelling achievement of the underachieving Students.

Summary of Analysis of Covariance of Instructional Approaches on Students' Spelling Achievement Scores. Insert Table 5 in here.

Table 5 shows that the calculated $\mathrm{f}$ value which is 22.492 was significant at $\mathrm{p}>0.05$. The hypothesis is therefore rejected; this result indicates that the instructional approaches had significant effect on students spelling 
achievement of the underachieving students. To confirm which variables are significantly different, a Duncan Multiple Range Test was carried out as indicated in table 6.

Insert Table 6 in here.

The table above indicates that all the three instructional approaches, which are grouped under letter ' $\mathrm{A}$ ' are more effective in enhancing the spelling ability of the students than the Conventional Instructional Approach grouped under 'B'.

Ho4: There will be no significant difference in the effects of MISIA, MCIA and the combination of MSIA and MCIA on the morphological achievement of the underachievers

Insert Table 7 in here.

Table 7 shows that the calculated $\mathrm{f}$ value which is 11.554 was significant at $\mathrm{p}>0.05$. The hypothesis is therefore rejected; this result indicates that the instructional approaches had significant effect on students morphological achievement. From the table also the treatment produced a significant difference in the post-test scores of the students when pre-test scores were used as covariates. This implies that a significant difference exists among the four groups. A follow up Duncan test was conducted to determine the actual source of difference that exists among the variables.

Insert Table 8 in here.

The table above indicates that all the three instructional approaches, which are grouped under letter 'B', have the same effect on the morphological ability of the students. However, MSIA which is grouped under letter 'A' is still the most effective, having the highest mean score.

Ho5: There will be no significant difference in the effects of MSIA, MCIA, MSIA+MCIA and CIA on the lexico-syntax achievement of the underachievers

Insert Table 9 in here.

Table 9 shows that the calculated f value which is 16.282 was significant at $\mathrm{p}>0.05$. The hypothesis therefore rejected, this result indicates that the instructional approaches had significant effect on the lexico-syntax achievement of the underachieving students. To confirm which variables are significantly different, a Duncan Multiple Range Test was carried out as indicated in table 10

Insert Table 10 in here.

The result in table 10 confirms that significant difference exists in the effectiveness of the four instructional approaches. The MSIA is rated ' $A$ ' which indicates that MSIA is the most effective of the four approaches in the lexico-syntax achievement of the students. This is followed by the combination of MSIA+MCIA, MCIA and CIA, which all fall within the same grouping of ' $\mathrm{B}$ '. Therefore, the null hypothesis is rejected.

Ho6: There will be no significant difference in the effects of MSIA, MCIA, MSIA+MCIA and CIA on the lexico-semantic achievement of the underachievers.

Insert Table 11 in here.

Table 11 shows that the calculated $\mathrm{f}$ value which is 20.355 was significant at $\mathrm{p}>0.05$. The hypothesis is therefore rejected; this result indicates that the instructional approaches had significant effect on the lexico-semantics achievement of the underachieving students. To confirm which variables are significantly different, a Duncan Multiple Range Test was carried out as indicated in table 12

The result in table 12 confirms that significant difference exists in the effectiveness of the four instructional approaches. The MSIA is rated ' $A$ ' which indicates that MSIA is the most effective of the four approaches in the lexico-semantics achievement of the students. This is followed by the MCIA,the combination of MSIA+MCIA and CIA, which all fall within the same grouping of ' $\mathrm{B}$ '. Therefore, the null hypothesis is rejected.

\section{Summary of the Findings}

The results showed that there was significant difference in the overall achievement in English vocabulary of the underachieving students taught using the four instructional approaches. Each of the three experimental groups performed significantly better than the control group, with the Multisensory Instructional Approach group performing best

Also the results from tables two to twelve revealed that there is significant difference in the effects of the three approaches on all the vocabulary dimensions (i.e pronunciation, spelling, morphology, lexico-syntax , and lexico-semantics) However, Multisensory Instructional Approach (MSIA) is the most effective Approach to teach 
vocabulary dimension to the underachieving secondary students. Government should supply schools with adequately trained teachers and multisensory instructional materials that provide concrete experience

\section{Conclusion and Recommendations}

Finding from this study have established the importance and relevance of MSIA to the teaching of English vocabulary to the under achievers.

The findings from this study also indicate that MSIA is the best approach for teaching all the five dimensions of vocabulary. i.e pronunciation, spelling, morphology, lexico-syntax, and lexico-semantics. This is in line with Sarka's (1978) finding that selected multisensory materials could help encourage students to put their feelings and thoughts into words in a more vivid and lucid manner which is after all what vocabulary acquisition and good reading and writing in L2 is all about.

This study also corroborates Singleton's (1999) findings that the availability of a mental ability emerges as a possible aid in the fixing of words in memory. The pedagogical implications of this is that teachers can put knowledge of these findings to good effect by making use of visual aids that bring real concept to students especially the underachievers.

In line with the above findings, it is recommended that L2 teachers should consider the interest of the underachieving students and give them special attention by employing the MSIA or the combination of MSIA+MCIA to teach them. This would greatly help the underachievers in acquiring both receptive and productive vocabulary skills. Above all it is recommended that teacher training programmes should be student-centered. Government should supply schools with adequately trained teachers and multisensory instructional materials that provide concrete experience that contribute to the efficiency, depth, and variety of learning.

\section{References}

Abolade, A. (2002). Learning and instructional materials. In Abimbola,I.O.(eds.) Fundamental principles and practice of instruction. Ilorin: Curriculum Studies and Educational Technology Department, University of Ilorin, Ilorin. pp. 35-42

Adeniyi, F. O. (2009). The English Structure. Ilorin: Haytee Press. (chapter two).

Agun, I. (1998). Fundamentals of Educational Technology. Ibadan: University press. (Chapter four).

Adejumobi, T. (2007). Applied Linguistics. Ibadan: Joytal printing press. (Chapter ten)

Azikwe, U. (1998). Language teaching and learning. Onitsha: Africana Fep. Publisher Limited. (Chapter seven)

Ganshow. (1998). Difficulty in Learning Second Language. New York: Macmillan. (Chapter twelve)

Genfen, R. (1980). Teaching English to less able learners. ELT Journal, 35 (1), 45-58

Kimseoh, O. (1976). Vocabulary Teaching: looking behind the word. ELT journal, 1 (50), 58-69.

Kruse, A. F. (2000). Vocabulary in Contexts. ELT Journal, 33 (3) 121-150

Lawal, R. A. (1990). English Communicative Skills and Methods for Teachers. Unpublished mimeograph. Institute of Education: University of Ilorin.

Lawal, R. A. (1991). A Diagnostic Study of the Reading Performance of Some Nigerian School Pupils. In S.O. Unoh (eds.). Literature and Reading in Nigeria NERDC, pp. 101-110

Lawal, R. A. (2001).Approaches, Methods, Techniques and their Interrelationships. In Abimbola, I.O. (eds.). Fundamental principles and practice of instruction. Ilorin: Curriculum Studies and Educational Technology Department. University of Ilorin, Ilorin Kwara State. pp. 72-85

Nelson, D. (2006). Contrastive Semantics in vocabulary instruction. TESOL Quarterly, 10(1), 123-130

Osuji, R.O. (2008). Teaching and Learning Vocabulary in Secondary Schools. Ilorin: Haytee press, (chapter sixteen). Sarka, S. (1978). Teaching Meaning out of Context. London: Longman (chapter sixteen).

Smirth, S. (1978). English Language Vocabulary. London: Oxford University Press, (chapter seven).

Thorne. F. (2008). Underachievement in English Language. New York: Macmillan, (chapter ten).

Tiffen, B. (1982). A Language in Common. London: Longman, (chapter sixteen).

Yusuf, M. O. (2009). Learning and Instructional Resources/Materials 11: motion Pictures, Film Strip and Slides. In Abimbola, I.O. (eds.) Fundamental principles and practice of instruction. Ilorin: Curriculum Studies and Educational Technology Department, University of Ilorin, Ilorin Kwara State. pp. 95-110 
Table 1. Summary of Analysis of Covariance of Instructional Approaches on Students Vocabulary Achievement Scores

\begin{tabular}{|l|l|c|c|c|c|c|}
\hline Source & $\begin{array}{l}\text { Type 111sum } \\
\text { of Squares }\end{array}$ & Df & Mean square & F & Sig & $\begin{array}{c}\text { Partial } \\
\text { Eta }\end{array}$ \\
\hline Model & $.5914 .996 \mathrm{~b}$ & 4 & 1478.749 & 63.958 & .000 & .690 \\
\hline Covariate & .2044 .129 & 1 & 2044.129 & & .000 & .435 \\
\hline INSAPP(Treatment) & .337 .131 & 3 & 1112.377 & & .000 & .557 \\
\hline Residual & .2658 .871 & 115 & 23.121 & & & \\
\hline Corrected Total & .8573 .867 & 119 & & & & \\
\hline
\end{tabular}

Table 2. Duncan Multiple Range Test of Dimensions of Significant Difference in the Effectiveness among the Variables investigated.

\begin{tabular}{|l|c|c|c|}
\hline & No of cases & Mean score & Duncan grouping \\
\hline MSIA & 30 & 55.20 & $\mathrm{~A}$ \\
MCIA & 30 & 45.73 & $\mathrm{~B}$ \\
MSIA+MCIA & 30 & 463.7 & $\mathrm{~B}$ \\
CIA & 30 & 39.23 & $\mathrm{C}$ \\
\hline
\end{tabular}

Means with the same letters are not significantly different

Table 3. Summary of Analysis of Covariance of Instructional Approaches on Students' Pronunciation Achievement Scores

\begin{tabular}{|l|c|c|c|c|c|c|}
\hline Source & Type 111 sum of & Df & Mean square & F & Sig & Patial Eta \\
\hline Corrected model & 394.530 & 4 & 98.633 & 46.022 & .000 & .616 \\
\hline Intercept & 386.146 & 1 & 386.146 & 180.178 & .000 & .610 \\
\hline PRTESPON & 146.372 & 1 & 146.372 & 68.298 & .000 & .373 \\
\hline INSAPP & 172.851 & 3 & 57.617 & 26.884 & .000 & .412 \\
\hline Error & 246.461 & 115 & 2.143 & & & \\
\hline Total & 15139.000 & 120 & & & & \\
\hline Corrected Total & 640.992 & 119 & & & & \\
\hline
\end{tabular}

Table 4. Duncan Multiple Range Test of Dimensions of Significant Difference in the Effectiveness among the Variables investigated.

\begin{tabular}{|l|c|c|c|}
\hline Variables & No of cases & Mean score & Duncan groupings \\
\hline MSIA & 30 & 12.733 & $\mathrm{~A}$ \\
MCIA & 30 & 11.200 & $\mathrm{~B}$ \\
MSIA+MCIA & 30 & 11.300 & $\mathrm{~B}$ \\
CIA & 30 & 8.733 & $\mathrm{C}$ \\
\hline
\end{tabular}

Mean with the same letters are not significantly different. 
Table 5. Summary of Analysis of Covariance of Instructional Approaches on Students' Spelling Achievement Scores.

\begin{tabular}{|l|c|c|c|c|c|c|}
\hline Source & $\begin{array}{c}\text { Type } 111 \mathrm{sum} \\
\text { of squares }\end{array}$ & Df & Mean Square & F & Sig & $\begin{array}{c}\text { Partial Eta } \\
\text { Squared }\end{array}$ \\
\hline Corrected model & 474.881 & 4 & 118.720 & 28.930 & .000 & .502 \\
\hline Intercept & 382.045 & 1 & 383.045 & 93.099 & .000 & .447 \\
\hline PRETESSP & 175.948 & 1 & 175.948 & 42.876 & .000 & .272 \\
\hline INSAPP & 276.898 & 3 & 92.299 & 22492 & .000 & .370 \\
\hline Error & 471.919 & 115 & 4.104 & & & \\
\hline Total & 15204.000 & 120 & & & & \\
\hline Corrected total & 946.800 & 119 & & & & \\
\hline
\end{tabular}

Table 6. Duncan Multiple Range Test of Dimensions of Significant Difference in the effectiveness among the variables investigated.

\begin{tabular}{|l|c|c|c|}
\hline Variables & No of cases & Mean score & Duncan grouping \\
\hline MSIA & 30 & 11.96 & $\mathrm{~A}$ \\
MCIA & 30 & 12.17 & $\mathrm{~A}$ \\
MSIA\&MCIA & 30 & 11.23 & $\mathrm{~A}$ \\
CIA & 30 & 8.23 & $\mathrm{~B}$ \\
\hline
\end{tabular}


Table 7. Summary of analysis of covariance of Instructional Approaches on Students' morphological Achievement scores

\begin{tabular}{|l|c|c|c|c|c|c|}
\hline Source & $\begin{array}{c}\text { Type 111 Sum } \\
\text { of Squares }\end{array}$ & Df & Mean square & F & Sig & $\begin{array}{c}\text { Partial Eta } \\
\text { Squared }\end{array}$ \\
\hline Corrected model & 329.154 & 4 & 82.289 & 19398 & .000 & .403 \\
\hline Intercept & 303.774 & 1 & 303.774 & 71.610 & .000 & .384 \\
\hline PRTESMOP & 161.396 & 1 & 161.396 & 38.046 & .000 & .249 \\
\hline INSAPP & 147.037 & 3 & 49.012 & 11.554 & .000 & .232 \\
\hline Error & 487.837 & 115 & 4.242 & & & \\
\hline Total & 9813.000 & 120 & & & & \\
\hline Corrected total & 816.992 & 119 & & & & \\
\hline
\end{tabular}

Table 8. Duncan Multiple Range Test of Dimension of significant Difference in the Effectiveness among the variables investigated.

\begin{tabular}{|l|c|c|c|}
\hline Variables & No of cases & Mean score & Duncan grouping \\
\hline MSIA & 30 & 10.67 & $\mathrm{~A}$ \\
MCIA & 30 & 7.80 & $\mathrm{~B}$ \\
MSIA\&MCIA & 30 & 8.37 & $\mathrm{~B}$ \\
CIA & 30 & 7.80 & $\mathrm{~B}$ \\
\hline
\end{tabular}

Table 9. Summary of analysis of covariance of Instructional Approaches on Students' morphological Achievement scores

\begin{tabular}{|l|c|c|c|c|c|c|}
\hline Source & $\begin{array}{c}\text { Type 111 Sum } \\
\text { of Squares }\end{array}$ & Df & Mean square & F & Sig. & $\begin{array}{c}\text { Partial Eta } \\
\text { Squared }\end{array}$ \\
\hline Corrected model & 179.095 & 4 & 44.774 & 15.254 & .000 & .347 \\
\hline Intercept & 425.905 & 1 & 425.905 & 145.383 & .000 & .558 \\
\hline PRTESMOP & 80.737 & 1 & 80.737 & 27.560 & .000 & .193 \\
\hline INSAPP & 143.095 & 3 & 43.698 & 16.282 & .000 & .298 \\
\hline Error & 336.896 & 115 & 2.930 & & & \\
\hline Total & 665.000 & 120 & & & & \\
\hline Corrected total & 515.992 & 119 & & & & \\
\hline
\end{tabular}


Table 10. Duncan Multiple Range Test of Dimensions of Significant Difference in the effectiveness among the variables investigated

\begin{tabular}{|l|c|c|c|}
\hline Variables & No of cases & Mean score & Duncan grouping \\
\hline MSIA & 30 & 8.67 & A \\
MCIA & 30 & 6.30 & B \\
MSIA\&MCIA & 30 & 7.00 & B \\
CIA & 30 & 6.67 & B \\
\hline
\end{tabular}

Mean with the same letter are not significantly different

Table 11. Summary of analysis of covariance of Instructional Approaches on Students' lexico-semantics Achievement scores

\begin{tabular}{|l|c|c|c|c|c|c|}
\hline Source & $\begin{array}{c}\text { Type 111 Sum } \\
\text { of Squares }\end{array}$ & Df & Mean square & F & Sig & $\begin{array}{c}\text { Partial Eta } \\
\text { Squared }\end{array}$ \\
\hline Corrected model & 609.816 & 4 & 152.454 & 51.701 & .000 & .643 \\
\hline Intercept & 242.112 & 1 & 242.112 & 82.106 & .000 & .417 \\
\hline PRTESMOP & 267.124 & 1 & 267.124 & 90.588 & .000 & .441 \\
\hline INSAPP & 180.063 & 3 & 60.021 & 20355 & .000 & .347 \\
\hline Error & 339.109 & 115 & 2.949 & & & \\
\hline Total & 11161.000 & 120 & & & & \\
\hline Corrected total & 948.925 & 119 & & & & \\
\hline
\end{tabular}

Table 12. Duncan Multiple Range Test of Dimension of significant Difference in the Effectiveness among the variables investigated.

\begin{tabular}{|l|c|c|c|}
\hline Variables & No of cases & Mean score & Duncan grouping \\
\hline MSIA & 30 & 12.10 & A \\
MCIA & 30 & 8.77 & B \\
MSIA\&MCIA & 30 & 7.90 & B \\
CIA & 30 & 8.13 & B \\
\hline
\end{tabular}

Mean with the same letter are not significantly different 